\title{
ISSUES AND ECONOMIC ROLE OF WAQF IN HIGHER EDUCATION INSTITUTION: MALAYSIAN EXPERIENCE
}

\author{
Farra Munna Harun, Bayu Taufiq Possumah, \\ M Hakimi Bin Mohd Shafiai, Abd. Halim Mohd. Noor
}

\begin{abstract}
Issues and Economic Role of Waqf in Higher Education Institution: Malaysian Experience. As early as 1980, the Malaysian federal government's spending on education, was the highest in East Asia and higher than the OECD average of $3.4 \%$ of GDP. This demonstrates that the Malaysian Government has big expenses from educational sector and respectively is amenability for Malaysian economic budget. In other side Waqf in Malaysia is one of large financial source that has not been fully explored. By using qualitative methodology through content analysis this paper attempt to explore the issues and economic role of Waqf in Malaysia, especially in Higher Education Institution (HEI) and attempt to study how Waqf fund empowering the education. This study found that taking the que from the institutions of Waqf, the exploration and development of waqf fund can be exalarate through the formation of formal organizations at state and federal level and rearrange the Malaysian educational budget and policy to support the better quality of HEI.
\end{abstract}

Keywords: Waqf; Issues; Higher Education Institution; Malaysia

\begin{abstract}
Abstrak. Isu and Peranan Ekonomi Atas Wakafpada Institusi Pendidikan Tinggi: Studi di Malaysia. Era 1980an, perbelanjaan pemerintah Malaysia dalam sektor pendidikan adalah yang terbesar di Asia Timur dan lebih tinggi dari negara-negara OECD, yaitu rata-rata $3.4 \%$ dari PDB. Hal ini menunjukkan bahwa Kerajaan Malaysia memilik budget besar dalam sektor pendidikan. Sebaliknya, waqf di Malaysia sebagai salah satu sumber finansial belum digali lebih dalam. Dengan menggunakan metode kualitatif dengan pendekatan analisa konten, penulisan ingin menggali isu yang lebih dalam berkenaan dengan peranan waqf secara ekonomi di Malaysia. Secara spesifik, penulisan ini mengkhususkan kajian peranan waqf dalam Institusi Pendidikan Tinggi dan bagaimana waqf bisa memprakarsai pendidikan secara umum. Kajian ini mendapati bahwa eksplorasi dan pengembangan dana wakaf pada institute waqf dapat diakselerasikan melalui pembentukan organisasi formal di tingkat negara bagian (propinsi) dan federal (pusat), serta dengan cara mengatur ulang anggaran pendidikan Malaysia dan kebijakan untuk mendukung kualitas institusi pendidikan tinggi yang lebih baik.
\end{abstract}

Kata Kunci: Waqf; Isu; Institusi Pendidikan Tinggi; Malaysia

Received: September 8, 2015; Revised: December 5, 2015; Accepted: December 21, 2015

Institut Islam Hadhari - Universiti Kebangsaan Malaysia; Kompleks Tun Abdullah Mohd Salleh

Universiti Kebangsaan Malaysia, 43600 UKM Bangi, Selangor Malaysia;

Universiti Malaysia Trengganu, 21030 Kuala Trengganu, Trengganu, Malaysia

Accounting Research Institute (ARI) - Universiti Teknologi MARA, Malaysia; SAAS Building, Universiti Teknologi

MARA, 40450 Shah Alam, Selangor, MALAYSIA.

Email: fmharun@gmail.com; btaufiq@gmail.com; hakimi@ukm.edu.my; drhalimnoor@gmail.com

DOI: $10.15408 /$ ijies.v8i1.2514 


\section{Introduction}

The concept of waqf (pl: "Awqaf" and "wuquuf") or in another terms is an "endowment", was developed by the Holy prophet Mohammad (SAW) and has played a vital role in fulfilling the needs of socio-economic of the Ummah. The term waqf is used in Islam to describe certain property, which is held and/or preserved for the confined benefit of any philanthropy use and disposition of it outside those specific objectives is thus prohibited. Thus, zakah and waqf can be set as an alternative solution to the poverty as a major obstacle in several modern Islamic countries.

We may begin by looking at the meaning of waqf from an everyday point of view to compliment the various definitions by language terminology or by scholars, which are plentiful if we search the Internet. Thus, waqf refers to a property or asset donated by its owner for the cause of Allah in perpetuity (forever), to be used for philanthropy for the benefit of the community or the public. Once the asset is made a waqf, it cannot be revoked, meaning that the donor of the waqf property cannot cancel this act and repossess or take back this property. Also, once the asset becomes a waqf asset, it can no longer be inherited nor sold.

Although Waqf is in fact a permanent form of endowment, but we should note that the act of performing a waqf is a voluntary act, and it is not compulsory as compared to zakat (giving alms), which becomes compulsory on a Muslim when his or her wealth reaches a certain minimum amount (Nisab). I have deliberately highlighted the phrase "a portion of one's assets" to highlight that Islam is a practical religion as we are encouraged to give or donate only a certain percentage of our wealth and not all of it. Waqf has four pillars, which forms the components or basic ingredients, for a transaction to become a waqf. As in any act of charity or philanthropy, the donor or benefactor (termed as waqif) is the person who has complete ownership of the asset or property, which is to be made waqf. Complete ownership means that the asset or property is free from any claims or encumbrances, meaning that a property, which is under mortgage or which is secured as collateral to a loan, does not constitute complete ownership by its registered owner.

The property or asset selected for waqf (termed mauquf) must be a Syariahallowed asset of value that is identifiable, quantifiable and non-perishable. For instance, a waqf of wine is invalid and items such as food or medicine cannot be made waqf as it perish on consumption. The intended beneficiary or recipient of the proceeds and benefits of the waqf asset (termed mauquf'alaih) must be alive (cannot be a deceased person) who can be a specific group, the community or the general public. In a waqf, the donor/benefactor or waqif can also be one of the recipients 
of the benefits of the asset he/she made a waqf. For instance, if I donated a piece of land as waqf and build a school on it, I can send my son or daughter as a student of this school. The waqif must demonstrate intent to establisha waqf via explicit or implicit statement to do so (termed sighah). Waqf is consummated when the waqif puts it clearly that he/she wishes to specifically make the subject property/asset into a waqf whereby the sighah or the form of agreement is decisive and clear, and not conditional on certain event(s). Waqf traditionally used for religious purposes, such as for Imam's salary, religious education, build a mosque and or to fund mosque's running expenses and so on. This kind of waqf categorized as Religious Waqf. It helps community to reach their religious satisfaction needs and to reduce the cost in providing religious facilities in the future. Unique things is, in the Islamic religious Waqf is that the Shari ah did not give any religious bodies, persons, or leaders managerial privileges or beneficiary's rights on any religious grounds. An Imam or preacher may be entitled to certain benefits from the revenues of a religious Waqf on one ground only, that is, if the name or position is assigned such benefits by the Waqf founder. We might came to conclusion that waqf adds another feature which is, waqf supposed ran by a legal body in order to create a boundaries between waqf founder and waqf itself in regarding benefit or distribution of waqf. Expected, by the civil management, waqf will have its' own framework, objectives, documentation and regulations to manage the waqf output.

Second type of Waqf is Philanthropic Waqf, which its' aim is to help the poor-society segment and support all the public facilities needs such as, public utilities, health services, public library, public transportation, public land-structure, and so on. Began by Prophet Muhammad PBUH, Umar who asked the Prophet, peace and blessings be upon him, what to do with a palm orchard he owned in the city of Khaibar and the Prophet, peace and blessings be upon him, said:

"Give it in charity (i.e. as an endowment) with its land and trees on the condition that the land and trees will neither be sold nor given as a present, nor bequeathed, but the fruits are to be spent in charity."(Bukhari)

The third Waqf is, Family Waqf. This type of waqf, actually, let the family have the fruits and the revenue. If only the Waqf has surplus, then it is allowed to distribute to the poor. The idea is arisen, and moralities of philanthropy we can simply mark a illustration that family Waqf is in fact bountiful in substance because it gives revenue/usufruct to individuals with no charges and it advances the welfare of forthcoming generations also reduces the future social welfare burden of philanthropies/governments.

Basically, The Waqf development in Malaysia is constantly bright and inspiring with the full support by the Malaysian government but as we known 
still not much elaborated in context relation to the higher education institution. Hence this paper aims to study and review what are the issues, challenges, and future directions of waqf based higher educational program in Malaysia.

\section{Literature Review}

Refer to Chowdhury, Ghazali and Ibrahim, (2011), the continuous existence and operation of any organization is crucial and depending on financial health. In the case of waqf, this matter is more essential because productive endowed assets are left idle due to insufficient revenue to sustain operational costs. As one of the mechanisms in the Islamic economic system, Waqf, is a perpetual voluntary charitable act (Sadeq, 2002), to promote equitable and just distribution of wealth. More over Singer, (2008) has stated that the contributions of waqf in the political and socioeconomic growth and development of Muslim countries and communities over the years were so pertinent so much and has been labelled as the most visible evidence of charity in Islam. Waqf assets were instrumental in providing social and economic safety valves through its role in promoting religion, education, shelter, health, food security and rural-urban transformation. Therefore in the tenth century, waqf has been replaced zakat as the vehicle for financing social economic development in Islamic societies (Singer, 2008).

In the modern era, Pirasteh (2011) has investigated the economic and operational efficiency of government and private-administered waqf in Iran. By using two ratios: the ratio disbursement to proceeds (which they termed the objective achieved index) and the ratio of remaining balance from years to total earnings (which they termed the expected income achieved index), they measure the extent of achievement to which the institution is fulfilling its objectives while the latter measures the degree to which the institution is able to maximize the generation and collection of waqf income while minimizing uncollectable earnings. They found that that privately-managed waqf performed better than governmentmanaged waqf.

\section{Methods}

The above background leads us to develop a study that will be spread out through particularly purposes and methodology. The purpose of this study was to investigate the role and issues of Waqf as one of sector financing and its development related to higher education institution. The functional mechanism of waqf linked to higher education institution in strengthening the socio-economic of ummah has not explained well, as well as government efforts to make waqf as 
an instrument of macro economic development. This is among the reasons why this research is needed. By using qualitative description method through content/ documents analysis this research basically attempt to complete grounded theory to the relevance references pertaining to Waqf and others philanthropy fund.

\section{Results and Discussion}

As a developed country, currently Malaysia faces a great challenge. The future success, both socio-cultural and economic of the nation depends on quickly and significantly improving the outcomes of the nation's education system. The people are also demanding that initiatives launched by the Government are consistent, well executed, and deliver on their promised outcomes (Harun, et.al, 2014). The people agree that the better future of a nation may be predicted trough how the nation managing their educational system. Education plays a central role in any countries not just to pursuit the better of economic growth and national development, but to pursuit the better quality of human resources as well who can execute the economic development itself. It is understood that the nation with high quality of education level tends to the better economic prosperity also.

As one of emerging countries, the Malaysian government has emphasized the important of education. Various policies have been taken by the government to narrow the gap between Malaysia and other developed countries and to force the internal educational system. The society also has large and more easily to access the information on current education development worldwide. Nevertheless, there is still empty room need to elaborate well especially in term of collaboration between government and non-government or private institution. In harmonizing to World Bank advocacy for knowledge basic development, Malaysian Government has put down various steps, which accumulated, in three specific objectives and known as Malaysia Education Blueprint: first, understanding the current performance and challenges of the Malaysian education system, with a focus on improving access to education, raising standards (quality), closing achievement gaps (equity), promoting unity amongst students, and maximizing system efficiency; second, establishing a clear vision and aspirations for individual students and the education system as a whole over the next 13 years; third, outlining a comprehensive transformation programmed for the system, including key changes to the Ministry that will allow it to meet new demands and rising expectations, and to ignite and support overall civil service transformation.

The Malaysian federal government's spending on primary and secondary education, as a percentage of Gross Domestic Product (GDP), was the highest in East Asia. In 2011, the amount spent, at 3.8\% of GDP or $16 \%$ of total 
government spending, was not only higher than the OECD average of $3.4 \%$ of GDP and $8.7 \%$ of total public spending respectively, but also at par with or more than top-performing systems like Singapore, Japan, and South Korea. In 2012, with an education budget of RM37 billion, the Government has continued to devote the largest proportion of its budget, $16 \%$ to the Ministry and $4 \%$ to Malaysian Gross National Income (GNI). This demonstrates the very real commitment from the government for education as a national priority (see Harun, et.al, 2014).

Table 1. The Malaysian Federal Government's Spending on Primary and Secondary Education

\begin{tabular}{cccccc}
\hline Year & $\begin{array}{c}\text { Total Educational } \\
\text { Expenditure }\end{array}$ & $\begin{array}{c}\text { Total Federal } \\
\text { Expenditure }\end{array}$ & $\begin{array}{c}\text { Gross National } \\
\text { Income (GNI) at } \\
\text { Market Price }\end{array}$ & $\begin{array}{c}\text { Percentage } \\
\text { of Total } \\
\text { Educational } \\
\text { Expenditure } \\
\text { Against }\end{array}$ & $\begin{array}{c}\text { Percentage of } \\
\text { Educational } \\
\text { Expenditure } \\
\text { Against GNI } \\
\text { at Market } \\
\text { Price } \\
\text { Total Federal } \\
\text { Expenditure }\end{array}$ \\
\hline 2010 & $28,253,024,345.13$ & $151,632,609,265.44$ & $770,993,000,000$ & 18.6 & 3.66 \\
\hline 2011 & $31,180,411,904.70$ & $182,593,788,337.96$ & $862,850,000,000$ & 17,07 & 3.61 \\
\hline
\end{tabular}

Source: Finance Division, Ministry of Education Malaysia

As one of important Islamic finance institution "Waqf" has been exists since the early Islam. "Waqf" is the catalyst institution to the economy and ummah development. These institutions also carry out the success of social warranty system in Malaysia besides others institution like "zakat", "sadaqah". Basically "waqf” not only as "ibadah" to Allah SWT, but it also have a wide meaning and overwhelm as an agent to the growth of all Muslims. Currently, the Waqf institution in Malaysia seems like not well function, causing by the certain constraints and problems besides the low social awareness of Waqf and it's management. The Malaysian government must overcome this constraints, increase the "waqf' awareness among citizens and also make a brand new concepts to see the "waqf" institution in Malaysia thrive through around the globe. 
Table 2. Waqf Properties in Malaysia

\begin{tabular}{|c|c|c|c|c|c|c|c|c|c|}
\hline \multirow[t]{2}{*}{ State } & \multicolumn{3}{|c|}{ General } & \multicolumn{3}{|c|}{ Specific } & \multicolumn{3}{|c|}{ Total } \\
\hline & Num & Hectare & Value (RM) & Num & Hectare & Value (RM) & Num & Hectare & Value (RM) \\
\hline Johor & 0 & 1.422 .80 & 0 & 0 & $1,729.50$ & 0 & 0 & $3,152.30$ & $7,000,5000.00$ \\
\hline Kedah & 164 & 158.62 & 164.00 & 1833 & $1,086.25$ & $1,833.00$ & 1997 & $1,244.88$ & 1,997 \\
\hline Kelantan & 77 & 16.01 & $5,690,274.00$ & 276 & 157.63 & $51,013,099$ & 383 & 173.65 & $56,703,373$ \\
\hline Melaka & 24 & 1.01 & 25.50 & 41 & 21.60 & 41 & 65 & 33.25 & 66.50 \\
\hline Negeri Sembilan & 10 & 11.651 .01 & 10.00 & 26 & 14.49 & 26 & 36 & 15.50 & 34 \\
\hline Pahang & 0 & 0 & 0 & 0 & 723.82 & 0 & 0 & 723.82 & $18,000,000$ \\
\hline Perak & 383 & 116.12 & 383.00 & 0 & 0 & 0 & 383 & 116.12 & 383 \\
\hline Perlis & 0 & 2.74 & 0 & 0 & 14.49 & 0 & 0 & 17.23 & $1,337,993$ \\
\hline Pulau Pinang & 0 & 220.03 & 0 & 0 & 559.23 & 0 & 0 & 779.26 & $850,000,000$ \\
\hline Sarawak & 0 & 6.86 & 0 & 0 & 4.04 & 0 & 0 & 10.90 & $1,416,781$ \\
\hline Sabah & 41 & $2,0062.66$ & 41.00 & 62 & 32.26 & 62 & 103 & $2,095.16$ & 103 \\
\hline Selangor & 0 & 235.63 & 0 & 0 & 31.82 & 0 & 0 & 265.45 & $200,000,000$ \\
\hline Terengganu & 311 & 581.66 & $13,591,985.5$ & 1260 & $1,878.58$ & $29,031,210.68$ & 1571 & $2,460.24$ & $42,623,196$ \\
\hline Commonwealth & 2 & 0.49 & 2.00 & 14 & 1.59 & 14 & 16 & 2.08 & 15 \\
\hline
\end{tabular}

Source: Jabatan Waqf, Zakat, dan Haji (JAWHAR) Malaysia

Documented on 2010, there are Waqf properties estimated over RM111 billion throughout Malaysia. The distribution of the endowment, using waqf classification can be seen on table 1 . From table 1, the number of general waqf is 996 units with total 6925.17 hectares whereas specific waqf land is 4744 units with 9825, 93 hectares. Therefore, the total waqf land-property is 16751.10 hectares throughout the country. The distribution by state is showed on table 2 . Terengganu has the largest waqf land with 5817.54 hectares, whereas Kuala Lumpur Federal Territory has the smallest, only 2.08 hectares. According to Department of Awqaf, Zakat and Hajj Malaysia [JAWHAR, (2013)], the number showed is not actual size of waqf land. Data shown at Table 2.

This is followed by issues and problems related to unsystematic waqf land registration at large. One of the issues of Waqf land in Malaysia was still over $70 \%$ allocated in mosques, as shown in the table below: 
Table 3. Waqf Land in Malaysia

\begin{tabular}{clcc}
\hline No. & Use of Waqf Land & Size (Acres) & Percentage of Total Waqf Land \\
\hline 1. & Mosque & 462.6238 & $75,04 \%$ \\
2. & Surau & 41.1742 & $6,68 \%$ \\
3. & Cemeteries & 2.5920 & $0,4 \%$ \\
4. & Schools & 50.5805 & $8,20 \%$ \\
5. & Charities/Orphanages & 11.3647 & $1,84 \%$ \\
\hline \multicolumn{2}{r}{ Total } & & $92,18 \%$ \\
\hline
\end{tabular}

Source: Jabatan Waqf, Zakat, dan Haji (JAWHAR) Malaysia

Refer to MAIN (State Islamic Religious Council Malaysia) as well, there are many Waqf land which is still unregistered under MAIN, this problem occur due to lack of knowledge among the community regarding the waqf land registration system.. The previous system adopted by the community is entrusting the Waqf land to the village leader or Imam that is led many of waqf land is unregistered. The problem is aggravated when the trustee is deceased and failed to bestow the waqf land to their next kin. Currently, the authority is hardly trying to ensure the entire Waqf land throughout the country soon will be registered in order to sustain the development. More over on the data, Malaysia has large size of waqf land to develop. If we estimate that Waqf land is $10 \%$ unregistered, meaning that the total of Waqf land is $20 \mathrm{~K}$ hectares. This amount represents the potential impact of Waqf to the development, especially for the Moslem community.

In 1999, MAIN Selangor launched waqf certificate under Section 17 Waqf Enactment to encourage Moslem citizen have shares units, and all collected fund will debited into Cash Waqf Group Fund, together with income received from waqf properties then all fund will disbursed for usage of the Moslem, includes education, health, social and spiritual concerns. This scheme actually helps people who does not have high value asset such as land, buildings, but they can still take part on waqf.

Kedah applied another system regarding waqf management. MAIN Kedah buy an asset or property, which this asset is for the usage of good deeds, and this property will divided to waqf, and sold to public then. This project called "Waqf Jemba". In the end, the public will purchase the land with estimation of one jemba is RM5 to RM30. Penang waqf management is manage through; (1) Development of Majoodsaw Waqf which about a 21 storeys Menara UMNO, 
Developed 8 units of commercial premises, 12 units of accommodation, 3 storeys of treatment centre, 5 units of shop lots and Developed 9 units of office shops; (2) Development of Khan Mohamad Waqf; which a Proposed development of 32 units of medium cost apartment (700sqft) and (3) Alimsah Waley Waqf Mosque, Lebuh Chulia; which Developed 56 units of accommodation premise, Proposed development of 43 units of 2 storeys terrace house (70'x20') and General Land resource (Isa, et.al, 2011)

As Quoting by Isa, Ali and Harun (2010), The Federal Territory manage Waqf land for the benefit of Ummah as follow, 1) Mosques, 2) Education centers, 3) Old Folks' and Orphanage, 4) Shelter centers, 5) A 34 storeys'A' class office building which will be rented out (ready in April 2011); 6) Dialysis Centre 7) Service apartments and 8) Waqf Share Scheme (see www.maiwp.gov.my).

Generally, by looking to the development Waqf in Malaysia over time we may accumulate several issues that counted as obstacles in managing Waqf property in Malaysia, as follow: First, law and legislation. The provisions of MAIN enactment, in term of Waqf not specifically provided as in the state of Selangor, Terengganu, Perak and Johor [see Baharuddin Sayin (2006), and Abdul Latif, et.al. (2006)] Due to the absence of this provision, there are some parties not responsible for the misuse of waqf, assuming that Waqf is the public domain that can be dominated and abused any time by simply arbitrary. Even now the Waqf is administered at the state level and provided in each of the Administration of the respective State, but the provisions of the Enactment of the Waqf is not exhaustive. It only emphasizes the administration and about simple procedure consecration. Substantive aspects are not emphasized even there is a conflict with the Islamic laws of Waqf itself (Mohd.Ali, et.al, 2006). For example, in restrictions the Waqf shall not exceed one-third of the property. This provision is also not assured and full recognition of the administration and management of the Waqf. This is due to the existence of restrictions and barriers and conflicts of jurisdiction between the State Legislature and Federal jurisdictions. By keeping the old law that is available, implications arises for the development of Waqf property. To overcome this problem, early action should be done through an amendment and approve the new rules specifically related to Waqf and the need for a broader interpretation of the number of sections contained in the available state enactments and other statutes should be consulted together. Among them are Akta Kanun Tanah Negara 1965 (Akta 56), Akta Kerajaan Tempatan 1976 (Akta 171), Akta Pemegang Amanah 1949 (Akta 208) dan Akta Pengambilan Tanah 1960 (Akta 486).

Referring to some regulations passed since the beginning of 1976 , specifically 
related to the enactment of Waqf and its rules have not been established except for a few states. Therefore, the need for some important rules relating to Waqf approved in accordance with other regulations for proper management and administration of Waqf and run more smoothly and practically. Among other things, Akta Pemegang Amanah 1949 (Act 208), [4] is too general and does not provide sufficient regulation to discuss the trust property for the Muslim. [5] This regulation may be compared to a number of domestic enactment forefront in terms of developing Waqf, such Selangor Enactment (No. 7 of 1999), Peraturan Kawalan Wakaf Perak 1959,KaedahkaedahWakafjohor (No.15 of 1983) and Enakmen Mengesah Wakaf Orang-orang Islam Terengganu (No.10/ 1972).

The important thing to pack is concerned with the definition of waqf itself, MAIN as trustee, vesting Waqf, the appointment of officials such the State Waqf officials, the appointment of Nazir and his authority on Waqf District, the procedures Waqf property, Waqif, conditions of waqf General and Special, the power of istibdal, investment and development of Waqf property, cancellation of Waqf and other required in accordance with Islamic law requirements and needs.

The provisions of this law can also be referred to other Muslim countries in the affairs of the waqf, such Waqf laws 1952 in Egypt, the Waqf Act 1954 in India, and Legal Principles Waqf 1972 in Libya. Similarly, the Ministry of Justice and Awqaf and Religious Affairs in Oman, Nort American Islamic Trust in the United States, the Ministry of Awqaf of Jordan and the Ministry of Awqaf and Islamic Affairs in Kuwait (Bakar, 1999) The existence of specific rules can be seen as important and effective aspect in controlling and protecting the interests of the trust property of Muslim.

Second, social awareness. Understanding of the rights and responsibilities of the waqf property is still less attention by the society today. There are several cases related to Waqf properties and the society. Such as those who rent the Waqf land but categorized ineligible for that land because they are not from the poor group. There are also Waqf land cases sold by the children of the original tenant to a third party without changing the name of owner and with high prices not under MAIN authority. The first (the original tenant) who inhabit the land had long died and was succeeded by the beneficiary or his family (wife or children). There is also a Waqf land sold and legally renamed without an agreement.

There are also properties that given by Waqif involving land that has no economic value. The assumption can be made that their "the property given" is to avoid land tax or land does not bring any benefit to the owner, either for agriculture or other development. Similarly, the mentality of many Muslims still believes that the Waqf can be hovered just in a mosque or Surau. To overcome this problem so 
as not to drag and prolonged, profound understanding should be brought to the community about the importance of waqf to be used in common by all Muslims, especially to those who are entitled to enjoy. Public interest must take priority over private interests.

In addition, awareness of the importance of waqf for the whole community needs to be upgraded. Community must also act and concerned about preserving the trust responsibility of the waqf to make an immediate report to the MAIN if there is any invasion that occurred on land endowment. Selfishness will not achieve justice concept of community planning and development of waqf land will not be realized as long as this negative attitude is not changed.

MAIN also needs to encourage the people to dedicating more their property of surplus to others to increase the amount of Waqf in Malaysia, particularly in General Waqf. The endowed land is the land with economic value and viable strategy for development in the present and not just endowed from undesirable surplus property and not able to be developed by the causes as mentioned before.

Third, commerciality in financial institution. Since the Ottoman period, reported that many of public utilities such as health services, education, and community welfare services, is provided by waqf system. Quoting Zuki as stated on Boudjellal (2008: 125), currently, the potential of waqf organizations is substantially unrealized. It is the conventional philanthropic institutions that are functioning more effectively. Therefore, there is a strong need to re-evaluate the current waqf institution and its needs. Efforts are also needed to develop a better approach for its financial management to increase its efficiency and performance.

JCorp has come up with their innovation on corporate waqaf (JCorp Annual Report, 2007). Former Prime Minister of Malaysia Dato'Seri Abdullah Ahmad Badawi has also suggested the establishment of World Waqf Fund (Tabung Waqf Sedunia) (Mahamood, 2007) and also establishment of Waqf Bond offered under Waqf Enactment (Negeri Sembilan) 2005 (Mahamood, 2007.) All these are among new innovations towards modern and contemporary platform for waqf development in Malaysia (Haneefah, et.al, 2009)

The Awqf Properties Investment Fund (APIF) which consist of several members around the globe, united for same goals and purposes, to develop new products on waqf sector, and invest in viable waqf real estate projects in accordance with shariah. APIF run a financing program to support the development of waqf land through several modes of financing, istina'a, murabahah, leasing and other appropriate Islamic financing mode (Ahmed, 2014) 
Table 4. Some projects funded by APIF:

\begin{tabular}{|c|c|c|c|}
\hline Name of Project & $\begin{array}{c}\text { Cost(USD } \\
\text { Million) }\end{array}$ & $\begin{array}{c}\text { APIF } \\
\text { Contribution } \\
\text { (USD Million) }\end{array}$ & Social Impact \\
\hline Makola Towers, Sri Lanka & 19.5 & 10 & $\begin{array}{l}\text { Providing Food, Shelter, } \\
\text { Clothes, Education, } \\
\text { Healthcare to Orphans }\end{array}$ \\
\hline $\begin{array}{l}\text { Commercial Complex for } \\
\text { Al-Magzoub Organization, } \\
\text { Khartoum, Sudan }\end{array}$ & 9.1 & 7.5 & $\begin{array}{l}\text { Teaching and Memorizing } \\
\text { the Quran Educational } \\
\text { Institution for Islamic } \\
\text { Studies }\end{array}$ \\
\hline $\begin{array}{c}\text { Commercial and Residential } \\
\text { Waqf for British Muslim } \\
\text { Heritage Centre, Manchester, } \\
\text { U.K }\end{array}$ & 28.92 & 11 & $\begin{array}{l}\text { Support the educational } \\
\text { and cultural programs and } \\
\text { activities of the Centre }\end{array}$ \\
\hline $\begin{array}{c}\text { Purchase of An Existing } \\
\text { Building for Islamic Trust } \\
\text { For Education and Culture- } \\
\text { Elyas Ar-Rumi, Dresden, } \\
\text { Germany }\end{array}$ & 13.4 & 6.4 & $\begin{array}{l}\text { Educational programs } \\
\text { for Muslims in Germany; } \\
\text { research funding and } \\
\text { activities aimed at improving } \\
\text { the image of Islam }\end{array}$ \\
\hline $\begin{array}{c}\text { Construction of a Waqf } \\
\text { Commercial Complex } \\
\text { Project In Cairo for Al-Azhar } \\
\text { Al-Shareef Egypt }\end{array}$ & 38.1 & 10.15 & $\begin{array}{c}\text { Support the center-Azhar to } \\
\text { teach Arabic to non-native } \\
\text { speakers }\end{array}$ \\
\hline
\end{tabular}

Fourth, different administration. Administration is the central pillar in the success of a plan. In terms of administration, the Waqf should be developed and expanded to all the functions, products and its importance in improving the quality of life of the Muslims. Management and implementation of Waqf in Malaysia should also be efficient and transparent in its success to elevate the maximum role of Waqf in the life of the Muslim world at large. Now, with the establishment of the Department of Awqf, Zakat and Hajj (JAWHAR) under the supervision of the Prime Minister on March 272004 and to assist the State Islamic Council (MAIN) undertake the development of Waqf. The State Islamic Council (MAIN) is still acting as the sole trustee of Waqf property in every state and assisted by the Department of Awqf, Zakat and Hajj (JAWHAR). All Waqf land development project should consent by the State Islamic Council (MAIN) and the Department of Awqf, Zakat and Hajj (JAWHAR) in advance.

Department of Awqf, Zakat and Hajj (JAWHAR) also act as a coordinator and mediator between the State Islamic Council (MAIN) and those who intend to develop the Waqf Properties. The result of collaborative effort between the Department of Awqf, Zakat and Hajj (JAWHAR) and State Islamic Council (MAIN) the 11,019.82 
hectares of Waqf land are 4,836.5 hectares of Waqf general, and Waqf special 6,255.55 hectares of land have been developed in 2012. Therefore, the cooperation between the Department of Awqf, Zakat and Hajj (JAWHAR) and State Islamic Council (MAIN) only need to be improved and intensified. Both parties must also "walkabout" launch campaigns, awareness courses to all members of the community about the Waqf, formed a special committee, and seek Waqf funds by large interestedcompanies in developing the Waqf property in Malaysia. Inadditional, in efforts to streamline the management of Waqf across the states in Malaysia also needs to be done, it is seen as being able to improve the quality of management of Waqf properties itself in Malaysia.

MAIN's management is related to waqf properties in Malaysia, MAIK also practiced the same system as MAIS (Selangor). Other than that, joint ventures in agriculture and farming with government agencies such as FAMA, MARDI, RISDA and many morecan be done to enrich waqf properties as done by MAIJ (Johor). To improve to a more efficient and effective database, MAIK can follow the example of JAIM (Malacca) (Isa, 2011)

Waqf asset usually regulate by an institution, called Baitul Mal. That is the reason why BM performance on efficient waqf management is a mandatory. Currently, BM concept has shown narrowing down regarding its function and its role in the Economy. The actual fact is far beyond the truest sense of BM concept back in the glorious time of Islam. Indeed, the distinction between those eras is due to economy climate changes. Nevertheless, the implementation of BM concept nowadays has degraded and need to be improved on its services.

Waqf Unit Divisionis one of small division, joint with BM unit and led by several MAIN staffs who responsible regarding the property and other matters.. Based on that fact, it is clearly showed that MAIN has limited staff and labor that can run the waqf administration; this is the major problem for them to run waqf administration smoothly. It is impossible to plan and execute the program perfectly. Staffs are pushed to bear all the responsibilities, which involved two large institutions at the same time, BM and Waqf. If we refer to the development of the two institution, apparently MAIN is preferably and focusing on BM institution. Possibly due to certain factors, waqf institution is less noticeable regarding its role and its function, which is, shall be conducted.

The implication of the merger of two institutions is, indirectly will effect the jurisdiction allocated to Waqf Unit become restricted and limited. . The overlapping of job description will also lead narrow down staff's authority. Thus this issue will give impact in determining policies and decisions of the project implementation. Waqf Unit had to go through rather complicated process. Any project should have permission from the Council and providential by the KDYMM al-Sultan. Hence 
Al-Iqtishad: Jurnal Ilmu Ekonomi Syariah (Journal of Islamic Economics) Vol. 8 (1), January 2016

this imbalance scenario will affect the entire aspect of waqf administration including development and financial, hand-over ownership, data provision and information, location monitoring and waqf land rental, and other. This negative impression resulted on relatively slow and difficult to take an action.

Public spending on education; total (\% of government expenditure) in Malaysia was last measured in 2013, according to Ministry education consists of current and capital public expenditure on education includes government spending on educational institutions (both public and private), education administration as well as subsidies for private entities (students/households and other privates entities) in Malaysia shown as Table 5:

Table 5. Malaysian Education Expenditure

\begin{tabular}{|c|c|c|c|}
\hline \multirow[t]{2}{*}{ Programme } & $\begin{array}{l}\text { Actual Expenditure } \\
2011\end{array}$ & $\begin{array}{l}\text { Actual Expenditure } \\
2012\end{array}$ & \multirow{2}{*}{$\begin{array}{l}\begin{array}{c}\text { Actual Expenditure } \\
2013\end{array} \\
\text { RM (\%) } \\
\end{array}$} \\
\hline & RM (\%) & RM (\%) & \\
\hline Educational Operation Mgt & $\begin{array}{l}24,204,370.61 \\
0.10\end{array}$ & $\begin{array}{l}24,092,914.11 \\
0.08\end{array}$ & $\begin{array}{l}27,583,500 \\
0.1\end{array}$ \\
\hline Pre-School & $\begin{array}{l}294,816,596.61 \\
1.81\end{array}$ & $\begin{array}{l}396,243,375.33 \\
1.33\end{array}$ & $\begin{array}{l}488,066,800 \\
1.75\end{array}$ \\
\hline Primary & $\begin{array}{l}12,257,447,203.98 \\
49\end{array}$ & $\begin{array}{l}14,525,016,817.35 \\
48.88\end{array}$ & $\begin{array}{l}13,076,510,700 \\
46.94\end{array}$ \\
\hline Secondary & $\begin{array}{l}10,056,661,594.24 \\
40.20\end{array}$ & $\begin{array}{l}12,184,681,526.67 \\
40.84\end{array}$ & $\begin{array}{l}11,859,253,100 \\
42.57\end{array}$ \\
\hline Hostels & $\begin{array}{l}321,840,094.65 \\
1.29\end{array}$ & $\begin{array}{l}367,580,081.50 \\
1.23\end{array}$ & $\begin{array}{l}365,164,100 \\
1.31\end{array}$ \\
\hline Management of State Adm & $\begin{array}{l}636,242,375.42 \\
2.54\end{array}$ & $\begin{array}{l}759,437,418.90 \\
2.55\end{array}$ & $\begin{array}{l}609,123,700 \\
2.19\end{array}$ \\
\hline Technical Education & $\begin{array}{l}398,899,864.62 \\
1.59\end{array}$ & $\begin{array}{l}372,238,248.65 \\
1.25\end{array}$ & $\begin{array}{l}311,769,500 \\
1.12\end{array}$ \\
\hline Islamic Education & $\begin{array}{l}561,655,705.33 \\
2.24\end{array}$ & $\begin{array}{l}660,991,202.38 \\
0.34\end{array}$ & $\begin{array}{l}600,425,300 \\
2.16\end{array}$ \\
\hline Special Education & $\begin{array}{l}82,953,137.72 \\
0.33\end{array}$ & $\begin{array}{l}100,338,720.48 \\
0.34\end{array}$ & $\begin{array}{l}102,901,500 \\
0.37\end{array}$ \\
\hline $\begin{array}{l}\text { Fully Residential and } \\
\text { Excellent School }\end{array}$ & $\begin{array}{l}324,925,570.95 \\
1.30\end{array}$ & $\begin{array}{l}385,915,058.91 \\
1.29\end{array}$ & $\begin{array}{l}350,002,600 \\
1.26\end{array}$ \\
\hline $\begin{array}{l}\text { Sports, Arts, and } \\
\text { Co-curriculum }\end{array}$ & $\begin{array}{l}51,755,988.63 \\
0.21\end{array}$ & $\begin{array}{l}59,429,729.96 \\
0.20\end{array}$ & $\begin{array}{l}63,501,800 \\
0.23\end{array}$ \\
\hline Private Education & $\begin{array}{l}2,370,973.53 \\
0.01\end{array}$ & $\begin{array}{l}2,628,540 \\
0.01\end{array}$ & $\begin{array}{l}2,645,900 \\
0.01\end{array}$ \\
\hline Total & $25,014,773,477.29$ & $29,833,553,634.24$ & $27,856,948,500$ \\
\hline
\end{tabular}

Source: Finance Division, Ministry of Education Malaysia 
While economic/financial institutions are a very large component of the Islamic reforms undertaken in the last 25 years, there also have been very important developments in supporting areas, especially in the education and legal spheres. The first was the establishment of the International Islamic University Malaysia in 1983. Although originally envisioned as an institution funded by the International Islamic community, the government of Malaysia has almost exclusively backed the IIUM. To date, the IIUM offers an integrated curriculum in courses such as economics, law, Islamic revealed knowledge, education, human/social sciences, engineering, architecture, medicine and basic sciences, taught in English (with some courses in Arabic). The underlying mission of the University is to produce graduates who are not only professionally competent, but imbued with good values, from an Islamic perspective. Since its first graduates in 1987, the IIUM has so far produced more than 20,000 graduates who have joined both the public and private sectors. In addition, the university is involved in providing diplomas and other short courses to Qadis (Shariah court judges), lawyers, businessmen and members of the public on various aspects of Islam related to their own fields.

In 1987, through the IIUM, the government set up the International Institute of Islamic Thought and Civilization (ISTAC), under the Directorship of Malaysian scholar Syed Muhammad Naquib al-Attas, with the objectives of promoting and undertaking more serious research in the fields of Islamic thought and civilization. In 1992, the Institute of Islamic Understanding (IKIM) was set up under the auspices of the Prime Minister's Department with the objective of providing a proper understanding of Islam, its principles and values to all Malaysians, especially the nonMuslims. In the mid 1990s, the government also set up the Islamic University College of Malaysia (Kolej Universiti Islam Malaysia), which was later renamed Islamic Science University of Malaysia (Universiti Sains Islam Malaysia), to provide more opportunities for students, especially those coming from religious secondary schools, to pursue their higher education in all professional areas by combining knowledge from both revealed and human sources of knowledge.

In early millennium decade, 2001, Research Center for Islamic Economics and Finance University Kebangsaan Malaysia (EKONIS UKM), was established as centre of excellence by Ministry of Higher Education. The primary objective of EKONIS is to foster research advancement in the fields of Islamic economics and finance. To support this objectives, EKONIS fully activities include research, publications, organizing workshop, and roundtable discussion. EKONIS attempts to distinguish itself in terms of high reputation in academic achievement, teaching excellence and make and oustanding contribution to the Islamic economics and finance fields.

Last, the establishment of the International Centre for Education in Islamic Finance (INCEIF) in 2006 represents an investment in Malaysian human capital 
to support the global development of the Islamic financial services industry in Malaysia. Human intellectual capital plays a pivotal role in driving the performance and market competitiveness of the industry. Going forward, it will be the defining factor. The fast pace of innovation in global financial services in general and in the Islamic financial services sector in particular, will demand new expertise and skills. Indeed, there will be an increase in demand for adequately qualified professionals. In this environment, the creation of a substantial pool of talent and expertise is thus indispensable for the future growth of Islamic finance. Strengthening research and development capabilities is also important for enhancing the capacity for innovation to meet the diverse requirements of the rapidly changing global economy.

In associated with promote applied research in the area of Shari'ah and Islamic finance, Bank Negara Malaysia established International Shari'ah Research Academy for Islamic Finance (ISRA) in 2008, who will also act as a repository of knowledge for Shariah views or fatwas and undertake studies on contemporary issues in Islamic financial industry. ISRA will contribute towards strengthening human capital development in the areas of Shari'ah and provide platform for greater engagement amongst practitioners, scholars, regulators, academicians via research and dialogues, both in the domestic and international environment. Through pioneering research and rigorous intellectual dialogue, ISRA aims to promote innovation and dynamism into new boundaries of Islamic finance. It is envisioned that with greater research and dialogues, mutual respect and recognition would emerge within Islamic financial industry global community.

The presence of some Islamic finance as institution or research centre provide large opportunities for the contemporary Muslim ummah to revive the best of past Islamic traditions in envisioning and realizing the central role of awqf in the development of the ummah's education, particularly at the college and university levels. There is a real need to re-examine the awqf tradition as a source of societal values and as an institution in the light of contemporary challenges facing the ummah in the field of education. It is with this awareness that all Islamic Finance institution consider the choice of the role of awqf in the development of Islamic higher education as its theme as most appropriate to the ummah's current public needs. The main hope is that opportunities will help to break new grounds and chart new directions in Muslim thinking and practices on awqaf-based higher education.

As we already known that Waqf as an endowment can be used as a source of funds to facilitate education program, especially higher education institutions. Regardless currently waqf is more in the form of fixed assets, accordance with its philosophy the word waqf means to hold. Furthermore, waqf can be interpreted as follows, in order to withstand the physical value of waqf is should unchanged / 
decreased; only the benefit of the assets may be used. The concept of waqf can be considered or as to the liberation of a servant (a person who requires the need for education as a primary / daruriyat) to the educational needs.

The Malaysian government expenditure in education is in very significant amount, thus limiting the movement and the expansion of the education system, in a certain way, due to budget constraints, might causing longer time to achieve certain targets. Thus this paper drawing a waqf thought and management as capable framework to fit and can be the flexibly source of funds to facilitate and empower the education activities especially in higher education institution.

If we see the principle of waqf definition, to hold, than we can redefined and review the meaning of waqf itself, it to preserved, to maintained the value of waqf, so the assets will have no decreasing in terms of value. Here, Waqf is containing value element. That value we bring forefront and proposed for unifying ground for diverse opinions. The matter of traditional waqf, (form of fixed asset, movable asset or intangible) may change hand physically, as long as its value is preserved, so, the philosophy of waqf will not shifted.

The benefitof this idea is a switch from non-liquid capital to liquid capital; that the subject matter of waqf, just like in the case of cash which may change hands, can be sold and charged, if (i) the disposal is in the interest of the waqf, (ii) complies with general principles of Shari'ah and (iii) is suitable to the nature of waqf. Their value, that provided always kept as waqf, and for the same purpose, in perpetuity. This corresponds to the spirit of the hadith, and as al-Salahat contends, should be decided according to the interest of community, nature, or need of waqf, and the demand of time and circumstances [Al Salahat in Sabit and Hamid 2006)]

Waqf is expected to alleviate the burden of government budget in education cost for all citizens. Following to the current waqf issues, as mentioned earlier, there are many waqf and or waqf assets is unregistered and not utilized yet. Therefore the waqf management still needs improvement in all aspects, including the governance of waqf asset inventory. Furthermore, existing waqf assets can be utilized to facilitate education either directly (waqf land or building / fixed property assets can be used as an office building/campus building) and indirect (waqf assets that produce high profits to be used for education fund). Consequently, Waqf cash can be applied to for building/office manufactory at waqf land, orto facilitate operational cost such as scholarships, providing books, staffs and lecturer salaries and other costs.

The partnership between the Government and Private sector in education sector is necessary. Both parties should take role and has the same responsibility to achieveeducation sustainability program. From the collaboration, it is expected, that, waqf institution initiation will be able for waqf assets both fixed and liquid assets 
to be managed, and in the end the benefit obtained from the assets management is proficient to facilitate the education program. In the long term, private sector with government will achieve the objective, to sustain the education system.

To empowering Higher Education Institution continuously, we cannot depend on non-solid-foundation only because sustainability of education system need sustainability of Waqf governance also as one of source of education fund, to lay this burden over the government is not wise. The government might have certain targets and limited budget in term of National economic account. But supporting to this governance, the policy makers are required also to derive a regulations regarding waqf asset management comprehensively. Hence, Waqf prospectus can be utilized to facilitate the ummah welfare needs, especially in higher education institution as combination between social awareness and government economic policy.

Basically, Waqf concept has developedalso by western society trough the "Endowment"Fund. Refer to investopedia, endowment fund isan investment fund set up by an institution in which regular withdrawals from the invested capital are used for ongoing operations or other specified purposes. Nonprofits, universities, hospitals and churches often use endowment funds. They are funded by donations, which are tax deductible for donorsan endowment fund is a permanent, self-sustaining source of funding. Endowment assets are invested. Each year, a portion of the value of the fund is paid out to support the fund's purpose, and any earnings in excess of this distribution are used to build the fund's market value. In this way, an endowment fund can grow and provide support for its designated purpose in perpetuity.

There are two basic types of endowment funds - true endowment and quasi endowment. A true endowment is defined as an endowment in which the donor stipulates that the corpus must be held inviolate and in perpetuity and invested to generate income to be spent for a specific purpose. Funds that are designated as endowment by the governing board of an institution (Board of Trustees) are called quasi endowment. These funds are also invested for the purpose of generating expendable income for a given purpose, but, as the funds are internally designated as endowment, the governing board can decide to spend the funds at any time. In some cases, donors will allow for the corpus of their endowment to be spent. This is also categorized as a quasi endowment. To spend the principal of a quasi endowment fund requires Board of Trustee approval or donor authorization.

Development of educational institutions such as Harvard, Oxford and Cambridge has done through the concept of Waqf. The report "The Sutton Trust Report (2003)" states: "the way forward is through endowment." The report states that endowment may be used to "invest in new facilities; Chairs ... pay for specific or general academic posts; undertake research, and pay Researchers competitively and 
create scholarship funds. "According to research by Razali Othman (2005) reported that in the year 2003, ten of biggest universities in the UK and USAhaveUSD74.24 billion and USD7.268 billion ofendowment fund. In 2003, the endowment fund at Oxford and Cambridge respectively worth USD3.2 billion. Through the plans on the Internet (2009), reported in 2008, Harvard endowment fund amounted USD36.9 billion which consist of separate over 11,000 funds. Entirely, towards 2000, the endowment funds from various sectors in the West have reached the value of USD2 trillion with total revenue over than USD700 billion.

\section{Conclusion}

This research conclude and expected can be facilitate and provide some considerations to the policymaker to develop a superiorly and successful economic development planning linked to particularly Waqf variable. Waqf fund injection can reduce the government expenditure for specific purposes, especially education. This fund will cover education expenses entirely such as its operational cost, books, teachers and staffs salary, including student scholarship. There are two channels for waqf to be disbursed for the education; whether it will inject to education fund directly or to be invested. Based on the several Issues and challenges, we may offer some suggestive measures as basis to overcome the issues in developing better education trough Waqf financing, such as: First, waqf istibdaly (from perpetuity to un-perpetuity). Second, university as waqf center of excellence.

According to Sabit and Hamid (2006), the perpetuity of dedication is intended but the perpetuity of the object is subject to interpretation. Following the provisionson the inalienability and non-transferability of the subject matter of waqf, this is followed by the decision of the court in Re Dato Bentara Luar Decd Haji Yahya Bin Yusof \& Anor V. Hassan Bin Othman \& Anor (1982) 2 MLJ 264, one would presume that both the perpetuity of dedication and its subject matter are intended in the meaning of the term perpetuity which is confirmed by the practice in Malaysia.

\section{References}

Chowdhury, M.S.R., et.al. (2011). Economics of cash waqf management in Malaysia: a proposed cash waqf model for practitioners and future researchers. African Journal of Business Management, 5(30), pp.12155-12163

Hamdan, N., Ramli, et.al. (2013). Accounting For Waqf Institutions: A Review On The Adaptation Of Fund Accounting In Developing The Shariah-Compliant Financial Reports For Mosque. Presented at World Universities' Islamic Philanthropy Conference 2013 (WIPCON 2013), “Transforming Islamic Philanthropy For Ummah Excellence”. Malaysia. 
Hanefah, M. et.al. (2009). Financing the Development of Waqf Property: The Experience of Malaysia and Singapore. Fakulti Ekonomi dan Muamalat International Conference on Waqf Laws and Management: Reality and Prospects. University Sains Islam Malaysia

Harun, F.M. (2011). The Role of Zakat And Cash Waqf To The Moslem Development Countries Economics System: Case Study Indonesia. (Unpublished Paper). Universiti Kebangsaan Malaysia

Harun, F.M, et.al. (2014). Cost Benefit Analysis on Government's Education Expenditure: Proposed Waqf Model for Education Capital. Presented on Asean Endowment Seminar 2014. USIM-Malaysia. 29 April 2014

Isa, Z, et.al. (2011). A Comparative Study of Waqf Management in Malaysia. 2011 International Conference on Sociality and Economics Development IPEDR vol.10 (2011)). IACSIT Press, Singapore

Kahf, M. (2010). Waqf and Sustaining Economic Development. Conference on Sustainable Development in the Light of Maqasid Al-Shariah. Kedah. Malaysia, Dec 13-15

Hoexter, M. (1998). Waqf Studies in the Twentieth Century: The State of the Art. Journal of The Economic and Social History of The Orient. Vol. 41: pp. 476-495.

Pirasteh, H. (2011). Efficiency criteria in the public and private waqf management: the Iranian experience. In: Essential Readings in Contemporary Waqf Issues. Kuala Lumpur: CERT

Romer. (1986). Increasing returns and long-run growth. Journal of Political Economy Vol. 94 (5), pp.1002-1037

Nik Hassan, N.M. (2008). The economics of Waqf institution. Paper presented in International Seminar on Waqf. Johor Bahru, 11-12 August

Sadeq, A.H.M. (2002). Waqf, Perpetual Charity and Poverty Alleviation. International Journal of Social Economics. Vol. 29 (2). pp 135 - 151

Sabit, M. \& M. Tahir. (2006). Innovative Modes Of Financing The Development Of Waqf Property. Paper at Konvensyen Wakaf Kebangsaan 2006, Jabatan Wakaf Zakat dan Haji, Jabatan Perdana Menteri, Malaysia

Sabit, M \& M. Tahir. (2007). Obstacles of the Current Concept of Waqf to the Development of Waqf Properties and the Recommended Alternative. Malaysian Journal of Real Estate, 1 (1).pp. 1-95

Singer, A. (2008). Charity in Islamic Societies. New York: Cambridge

Stevens, P. \& M. Weale. (2003). Education and Economic Growth. London: National Institute of Economic and Social Research. 